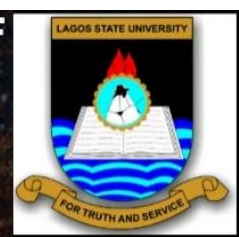

\title{
ANTIBACTERIAL EFFECTS OF AQUEOUS EXTRACT OF ONION AND GARLIC ON SOME CLINICAL BACTERIAL ISOLATES
}

Fashola Muibat Omotola 1*, Opere Bolanle Olaitan ${ }^{1}$, Saibu Gbemisola Morounke ${ }^{2}$ Bello, Olorunjuwon Omolaja ${ }^{3}$ Yovoyan Tobi Simeon ${ }^{1}$, Usman Olanike Falilat ${ }^{1}$,

${ }^{1}$ Department of Microbiology, Faculty of Science, Lagos State University, Nigeria

${ }^{2}$ Department of Biochemistry, Faculty of Science, University of Lagos, Nigeria

${ }^{3}$ Department of Biological Sciences, College of Natural and Applied Sciences, Wesley University, Ondo

\section{Correspondence}

Fashola M. Omotola,

Department of Microbiology,

Faculty of Science, Lagos State University,

Lagos-Badagry, Lagos, Nigeria.

Phone: (234)8027927808

Email:muibat.fashola@lasu.edu.ng

\section{Funding information}

Personal Funding

\begin{abstract}
:
Introduction: Many medicinal plants produce antioxidants and antimicrobial properties which protect the host from cellular oxidation reactions and other pathogens highlighting the importance of search for natural antimicrobial drugs.

Methods : The antibacterial activity of 25,50 and $100 \mathrm{mg} / \mathrm{ml}$ aqueous extract of garlic and onion on Staphylococcus aureus, Salmonella Typhi, Pseudomonas aeruginosa and Escherichia coli isolates were carried out using agar well diffusion method. The antibacterial activities of the aqueous plant extract were measured by zones of inhibition.
\end{abstract}

Results: Inhibition zone diameter of $18 \mathrm{~mm}, 19 \mathrm{~mm}, 21 \mathrm{~mm}$ and 27 $\mathrm{mm}$ were observed for E.coli, P.aeruginosa, S.aureus, and S. Typhi respectively using $100 \mathrm{mg} / \mathrm{ml}$ of garlic while for onion, $11.5 \mathrm{~mm}, 12$ $\mathrm{mm}, 12 \mathrm{~mm}$ and $13 \mathrm{~mm}$ inhibition zone diameter were observed for the same bacteria isolates respectively. It was observed that the increase in concentration of garlic is needed for better antibacterial activity while increasing concentration does not have a significant effect on the antibacterial activity of onion.

Conclusion: Garlic extract showed greater antimicrobial potential compared with onion extract. Thus, aqueous garlic extract may be more effective in the treatment of bacterial infections in order to overcome the problem of multidrug resistance of bacterial pathogens.

Key words: Antibacterial activity, Bacteria, Extracts, Garlic, Onion.

All co-authors agreed to have their names listed as authors.

This is an open access article under the terms of the Creative Commons Attribution License, which permits use, distribution and reproduction in any medium, provided the original work is properly cited.

(C) 2018 The Authors. Journal of Research and Reviews in Science - JRRS, A Publication of Lagos State University 


\section{INTRODUCTION}

The usage of medicinal plants has been given more attention as a result of its minimal or no side effects, better patient tolerance, low-priced, easy accessibility and wide range of applications [2]. More than $80 \%$ of the world population relies on traditional medicine for their primary health care needs. Plants are endowed with wide diversity of secondary metabolites, such as tannins, terpenoids, alkaloids and flavonoids, which have been found in vitro to have antimicrobial properties. [2,6]. As a result of the various inherent properties of medicinal plants, numerous plants are now being in used in part or as a whole to treat different types of diseases. Active components of plants are now being explored, isolated and processed into drugs with slight or no negative effects [20]. Onion and garlic are example of such medicinal plants with continued growing interest.

Onion (Allium sativum) and garlic (Allium cepa) are among the first cultivated vegetable all over the world as a result of their long storage period and transferability. They have over 500 members that differ in color, taste and appearance but close in neutraceutical, biochemical and phytochemical content [22]. The major component of garlic and Onion are water which is 85-90 $\mathrm{g} / 100 \mathrm{~g}$ and $60-70 \mathrm{~g} / 100 \mathrm{~g}$ fresh weight, respectively. The organosulphur containing compounds are the most important potent components which with other several phenolic compounds stir up vast interest [26, 23]. The mature whole Alliums comprise mainly of cysteine sulfoxides, and when tissues are crushed, the enzyme allinase is released, converting the cysteine sulfoxides into the thiosulfinates. These compounds are reactive, volatile, odor producing and lachrymatory [7].

Garlic and onion are known to have many biological activities such as antimicrobial, antioxidant, anticarcinogenic immunomodulatory, anti-cholesterol and biotic action $[33,28]$. The bulb is antihelmintic, antiinflammatory, antiseptic, antispasmodic, carminative, diuretic, expectorant, febrifuge, hypoglycemic, hypotensive, lithontripic, stomachic and tonic [9]. The high content of organo-sulphur containing compounds such as allin and allicin and their breakdown products are responsible for the biological and medical effects of garlic and onion [31]. Onion contain high content of flavonoids such as quercetin which are absent in garlic [30]. Flavonoids are a second class of health enhancing chemical compounds active against microorganisms; they have been found in-vitro to be effective antimicrobial substances against a wide range of microorganisms [32]. Garlic on the other hand contains almost three times as much sulfur-containing compound as onions (11-35 mg/100 g fresh weight). Several studies have shown that garlic and onion exhibit a broad antibacterial activity against both Gram positive and Gram negative bacterial pathogens that are known to resist different classes of antibiotics implicated in their treatment $[12,25,13,27]$.
Bacterial resistance is of growing concern to medical practice worldwide which impairs the effectiveness of antimicrobial agents [35] resulting in considerable increased illnesses and death rate. Staphylococcus aureus is a notorious antibiotics resistant bacterium, infections caused by antibiotics resistant strains have reached epidemic proportions worldwide. S. aureus is a major cause of nosocomial infections of surgical wounds and infections associated with indwelling medical devices [10]. Pseudomonas aeruginosa on the other hand is an important cause of Gram negative bacterial infection, the $4^{\text {th }}$ most commonly isolated nosocomial infections agent that causes variety of systemic infections particularly in immunosuppressed host [39]. Most E.coli strains are however harmless, but some serotypes are pathogenic and have been implicated in most several cases of urinary tract infection [17]. Salmonella Typhi is another important pathogen that causes enteric fever, an endemic disease in the tropic and sub-tropic (Asia and Africa) which has become a serious public health problem in developing countries of the world. Methicillin resistant $S$. aureus, $P$. aeruginosa and $E$. coli are among the most problematic drug resistant bacteria encountered today. Increasing frequency to several antibiotics has also been reported in several strains of Salmonella $[38,29]$. One of the measures to combat the increasing rate of resistance in the long run is to have continuous investigation for new, safe and effective antimicrobials as alternative agents to substitute with effective one.

The promising results obtained from the various studies on the antimicrobial properties of garlic and onion necessitates the need for more studies on the antibacterial activities of these plants on different clinical bacteria isolates. This study was therefore undertaken, to explore the antibacterial properties of the crude aqueous extracts of onion and garlic on four clinical bacterial isolates: S.aureus, S.Typhi, P.aeruginosa, and E.coli.

\section{MATERIALS AND METHODS}

\section{Collection of test organisms}

The test organisms; $P$. aeruginosa, S.Typhi, S. aureus and E.coli were collected from the Microbiology laboratory unit of Lagos University Teaching Hospital (LUTH) Idi-Araba, Surulere, Lagos State. All the cultures were obtained in pure form and subcultured on nutrient agar slants which were kept at $4^{\circ} \mathrm{C}$ until ready for use.

\section{Collection of plant materials}

Onion and garlic plants were purchased from the vegetable section of lyana Iba market, Ojo, Lagos State. It was identified taxonomically at the Department of Botany, Faculty of Science, Lagos State University, Ojo.

\section{Preparation of aqueous plants extracts}

The garlic and onion bulbs were cleaned peeled; sun dried and cut into small pieces and then grounded using 
an electric blender and placed in clean container. The aqueous extracts were obtained by soaking 200 gram of the edible portion of the garlic and onion powder in $(100 \mathrm{ml})$ distilled water and allowed to stand for (72 h). The homogenate was sterilized by filtration (using millipore $0.45 \mu \mathrm{m}$ pore-size filter to give a crude aqueous extract which was freeze dried in a lyophilizer and stored aseptically until used. The various concentration used in the study was later prepared by weighing appropriate grams of the onion and garlic in known volume of sterile distilled water.

\section{Antibacterial activity using agar diffusion assay}

This was done according to the method described by Cheesebrough [8]. Sterile inoculating loop was used to pick 3-5 colonies of well isolated colonies on the cultured plates and emulsified in $3 \mathrm{ml}$ of physiological normal saline. The turbidity of the suspension of the test organisms obtained was adjusted to match the 0.5 McFarland's standard. The cultures were swabbed on the surface of sterile Mueller Hinton agar plates using a sterile cotton swabs. The sterile swab sticks were used to spread by streaking the organism all over the surface of the agar and allowed to dry for about 5 minutes. Sterile cork borers were used to made wells of $9 \mathrm{~mm}$ in diameter in the already solidified agar. Using a micropipette, $100 \mu \mathrm{l}$ of different concentrations of the garlic and onion extracts $(100 \mathrm{mg} / \mathrm{ml}, 50 \mathrm{mg} / \mathrm{ml}, 25$ $\mathrm{mg} / \mathrm{ml}, 12.5 \mathrm{mg} / \mathrm{ml}$ and $6.25 \mathrm{mg} / \mathrm{ml}$ were added to the wells in the plates and allowed to stand for about one hour for proper diffusion. The plates were then incubated in an upright position at $37^{\circ} \mathrm{C}$ for 24 hours. The diameter of inhibition zones was measured in millimeter $(\mathrm{mm})$ and the results were recorded.

\section{Determination of minimum inhibitory concentration (MIC)}

The minimum inhibitory concentration (MIC) was determined by the broth dilution method of Weigand et al. [41]. The aqueous extracts were diluted to various concentrations ranging from 100 to $6.25 \mathrm{mg} / \mathrm{ml}$ in sterile distilled water. $500 \mu \mathrm{l}$ of each concentration were added to $2 \mathrm{ml}$ sterile nutrient broth in test tubes. Then $1 \mathrm{ml}\left(10^{8}\right.$ $\mathrm{cfu} / \mathrm{ml}$ ) of the test microorganism was added to the content of the test tubes and the tubes were incubated at $37^{\circ} \mathrm{C}$ for $24 \mathrm{~h}$. One milliliter $(1 \mathrm{ml})$ of the standardized inocula were also pipetted into the test tubes containing sterile nutrient broth and used as positive control. The MIC was taken as the lowest concentration of extracts that did not permit any visible growth for each of the test bacteria [37].

\section{Determination of minimum bactericidal concentration (MBC)}

The MBC of the extracts was determined using the method of Tagoe and Gbadago [37]. Samples was taken from the broth tubes that showed no change in turbidity and introduced into freshly prepared nutrient agar plates and incubated at 18-24 h. The lowest concentration of the extracts that showed no visible growth was recorded as the minimum bactericidal dose.

\section{RESULTS AND DISCUSSION}

The present study examines the antibacterial potential of different concentrations of aqueous extracts of onion and garlic against four pathogenic bacteria species; P.aeruginosa, S.aureus, E.coli and S.Typhi. It was observed that antibacterial activities of the aqueous garlic and onion extracts on these pathogens were found to be concentration dependent. Lower concentration of $12.5 \mathrm{mg} / \mathrm{ml}$ and $6.25 \mathrm{mg} / \mathrm{ml}$ of the aqueous garlic and onion extracts could not inhibit the growth of the pathogenic bacteria (Figures $1 A$ and $B$ ).
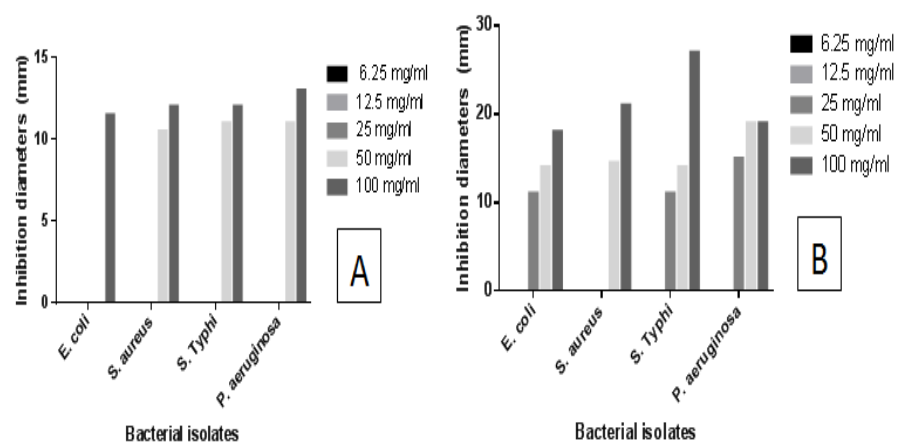

Figure 1: Antibacterial activity of various concentrations of aqueous extracts of $(A)$ onion and $(B)$ garlic on the bacterial isolates.

Generally, the bacteria growth were inhibited at concentrations of $50 \mathrm{mg} / \mathrm{ml}$ and $100 \mathrm{mg} / \mathrm{ml}$ for the two plants extracts with the exception of E.coli that was not inhibited at $50 \mathrm{mg} / \mathrm{ml}$ of the aqueous onion extract. This result is in agreement with the results of Lekshmi et al. [25], Kabrah et al. [21] and Shakurfow et al. [34] that also reported increased antibacterial activity of garlic and onion extracts at higher concentration of the plant extracts used. Reduced antibacterial activity recorded for E.coli in this study is in accordance with Bakht et al. [4] who also showed least antibacterial activity of aqueous onion extracts on E.coli tested in their study. Likewise the results of Azu and Onyeagba [3] and Srinivasan et al. [36] also supported the results obtained in this study.

Garlic extract was found to be more effective at concentration of $100 \mathrm{mg} / \mathrm{ml}$ than onion extracts in inhibiting the bacteria growth as shown in Figure 1. S.Typhi and S.aureus were the most sensitive of the four bacteria pathogens to the aqueous garlic extracts with the zone of inhibition ranging from $27 \mathrm{~mm}$ in S.Typhi to $21 \mathrm{~mm}$ in S.aureus while $E$. coli and $P$.aeruginosa recorded $18 \mathrm{~mm}$ and $19 \mathrm{~mm}$ as shown in Figure 2. At concentration of $50 \mathrm{mg} / \mathrm{ml}$, good activity was still recorded for the aqueous garlic extracts on the bacteria pathogens and activity decrease at $25 \mathrm{mg} / \mathrm{ml}$ as seen in Figure 1B. The higher antibacterial activity recorded for garlic could be attributed to the fact that garlic contains about three times as much sulphur containing compounds as onion [24]. Increased antibacterial activities of garlic to onion extracts have 
been reported by many authors. Hamza [16], showed that the aqueous extract of garlic inhibited growth of several Gram positive and Gram negative bacteria studied. The antibacterial activity of the garlic extract obtained in this study is also similar to that reported by Esimone et al. [15] and Hindi [18] that showed good antibacterial activity of aqueous garlic extracts on both Gram positive and Gram negative pathogenic bacteria studied. The variation in the size of the inhibition zone among the different bacteria may also be due to the lipid content in the outer membranes of the organisms [14]. Allicin responsible for the antimicrobial activity of garlic is three times more effective on Gram-positive bacteria than Gram-negative bacteria. $E$. coli has membrane lipid content 10 times higher than $S$. aureus, making allicin to be trapped in this lipid content [27]. The least antibacterial activity of the aqueous garlic extracts against E.coli and Pseudomonas recorded in this study is also supported by Santas et al. [30].

The extent of the inhibitory effect of the onion extract could be attributed to the presence of the antimicrobial compounds and their dissolving ratio in the solvents and concentration doses [1]. Onions are known to have broad spectrum of antibacterial activity as a result of the presence of flavonoids and polyphenols [30]. The reduced antibacterial activity of onion extracts compare to garlic extracts obtained in this study could be attributed to the method of extraction used for the plants. Studies have reported good antibacterial activities of onion against many bacteria pathogens using organic solvents. Bakht et al. [4], reported that petroleum ether, ethyl acetate and chloroform extracts of onion inhibited the growth of $S$. aureus at both lower and higher concentration. This is also supported by Eltaweel [13] that reported better antibacterial activity of the methanolic extracts of onion on the growth of $S$. aureus compared to the aqueous extracts. Organic solvent are known to dissolve organic compounds better, hence liberate the active component required for antimicrobial activity [12]. The results of this study is in accordance with the work of [16], that reported reduced antibacterial activity of aqueous extracts of onion on Gram positive and Gram negative bacteria pathogens tested in their study. High molecular weight of the onion extract could also reduce its rate of diffusion [3].

The minimum inhibitory concentration is the lowest concentration of the plant extract needed to inhibit the growth of the microorganisms. It was observed that both garlic and onion extracts exerts bacteriostatic effects at $50 \mathrm{mg} / \mathrm{ml}$ concentration on the growth of S.Typhi, S.aureus and P.aeruginosa while E.coli were not inhibited at this concentration as shown in Table 1.
Table 1: Minimum Inhibitory concentration of aqueous extracts of onion and garlic against the bacterial strains

\begin{tabular}{|c|c|c|c|c|c|c|}
\hline \multirow[t]{2}{*}{$\mathrm{S} / \mathrm{N}$} & \multirow[t]{2}{*}{$\begin{array}{l}\text { Onion/Garlic } \\
\text { extract }\end{array}$} & \multicolumn{5}{|c|}{$\begin{array}{l}\text { Concentration of } \\
\text { extract }(\mathrm{mg} / \mathrm{ml})\end{array}$} \\
\hline & & 6.25 & 12.5 & 25 & 50 & 100 \\
\hline \multirow[t]{4}{*}{1} & \multicolumn{6}{|l|}{ E.coli } \\
\hline & Onion & - & - & - & - & - \\
\hline & Garlic & - & - & - & - & - \\
\hline & Control & - & - & - & - & - \\
\hline \multirow[t]{4}{*}{2} & \multicolumn{6}{|l|}{ S.aureus } \\
\hline & Onion & - & - & - & ++ & - \\
\hline & Garlic & - & - & - & ++ & ++ \\
\hline & Control & - & - & - & - & - \\
\hline \multirow{4}{*}{3} & \multicolumn{6}{|l|}{ S.Typhi } \\
\hline & Onion & - & - & - & ++ & ++ \\
\hline & Garlic & - & - & - & ++ & ++ \\
\hline & Control & - & - & - & - & - \\
\hline \multirow[t]{4}{*}{4} & \multicolumn{6}{|l|}{ P.aeruginosa } \\
\hline & Onion & - & - & - & ++ & ++ \\
\hline & Garlic & - & - & - & ++ & ++ \\
\hline & Control & - & - & - & - & - \\
\hline
\end{tabular}

Key: - No growth ++ Complete inhibition

The minimum bactericidal concentration (MBC) of the aqueous extracts of onion and garlic against the four bacterial isolates is depicted in Table 2 . 
Table 2: Minimum lethal concentration of aqueous extracts of onion and garlic against the bacterial strains.

\begin{tabular}{|c|c|c|c|c|c|c|}
\hline \multirow[t]{2}{*}{$\mathrm{S} / \mathrm{N}$} & \multirow[t]{2}{*}{$\begin{array}{l}\text { Onion/Garlic } \\
\text { extract }\end{array}$} & \multicolumn{5}{|c|}{$\begin{array}{l}\text { Concentration of } \\
\text { extract }(\mathrm{mg} / \mathrm{ml})\end{array}$} \\
\hline & & 6.25 & 12.5 & 25 & 50 & 100 \\
\hline \multirow[t]{4}{*}{1} & \multicolumn{6}{|l|}{ E.coli } \\
\hline & Onion & - & - & - & - & - \\
\hline & Garlic & - & - & - & - & - \\
\hline & Control & - & - & - & - & - \\
\hline \multirow[t]{4}{*}{2} & \multicolumn{6}{|l|}{ S.aureus } \\
\hline & Onion & - & - & - & - & - \\
\hline & Garlic & - & - & - & - & ++ \\
\hline & Control & - & - & - & - & - \\
\hline \multirow{4}{*}{3} & \multicolumn{6}{|l|}{ S.Typhi } \\
\hline & Onion & - & - & - & - & - \\
\hline & Garlic & - & - & - & - & ++ \\
\hline & Control & - & - & - & - & - \\
\hline \multirow[t]{4}{*}{4} & \multicolumn{6}{|l|}{ P.aeruginosa } \\
\hline & Onion & - & - & - & - & - \\
\hline & Garlic & - & - & - & - & - \\
\hline & Control & - & - & - & - & - \\
\hline
\end{tabular}

Key: No growth ++: Complete inhibition

It was observed that only garlic showed bactericidal effect on S.Typhi and S. aureus at concentration of 100 $\mathrm{mg} / \mathrm{ml}$ while no bactericidal activity was recorded for onion at all the concentrations tested. These results suggests that the $100 \mathrm{mg} / \mathrm{ml}$ concentration of the onion was not sufficient for the tested bacterial pathogens unlike the aqueous garlic extracts that showed bactericidal activity at $100 \mathrm{mg} / \mathrm{ml}$ concentration of the plant extracts. This inactivity may be due to plant maturity, extracting solvent, method of extraction and time of harvesting of plant materials and also that variations may also be due to the different active substances present in these plants [13]. The sensitivity LASU Journal of Research and Review in Science of the bacteria to aqueous garlic and onion extracts could be as a result of allicin the main active components of onion and garlic which exhibits its antimicrobial activity mainly by immediate and total inhibition of RNA synthesis, although DNA and protein synthesis are also partially inhibited, suggesting that RNA is the primary target of allicin action [40]. The sensitivity of the multidrug resistant bacteria pathogens recorded in this study is in accordance with previous studies that reported good antibacterial activity of Allium spp against multi drug resistant bacteria pathogens [19, $5,25]$.

\section{Conclusion}

It can be concluded that aqueous extracts of both garlic and onion have antibacterial activities against the tested bacteria pathogens and their antibacterial activities is concentration dependent. In addition, aqueous garlic extracts showed better antibacterial activity compared to aqueous onion extracts. Further studies are needed to evaluate the possibility on the use of combination of garlic and onion as an antibacterial agent or combination of garlic or onion with conventional antibiotics.

\section{ACKNOWLEDGEMENTS}

The authors acknowledge and appreciate the Microbiology laboratory unit of Lagos University Teaching Hospital (LUTH) Idi-Araba, Surulere, Lagos for the provision of the bacterial isolates used for the study.

\section{COMPETING INTERESTS}

The authors declare no conflict of interest.

\section{AUTHORS' CONTRIBUTIONS}

FMO designed the study, literature searches, gathered the data, interpreted the results and wrote the first draft of the manuscript; OBO contributed to the study design and edited the manuscript; SGM contributed to the study design, literature searches and manuscript edition. BOO interpreted the results and contributed to manuscript draft; YTS and UOS participated in sample collection, experimentation and data collation. All authors read and approved the final manuscript

\section{FUNDING}

No grant was received from any funding agencies.

\section{REFERENCES}

1. Abdel-Salam AF, Shahenda ME, Jehan BA. Antimicrobial and antioxidant activities of red onion, garlic and leek in sausage. Afr $\mathrm{J}$ Microbiol Res. 2014; 8(27): 2574-2582 
2. Arumugam G, Manjula P, Paari N. A review: Anti diabetic medicinal plants used for diabetes mellitus J Acute Dis. 2013; 2(3):196-200.

3. Azu N, Onyeagba R. Antimicrobial Properties Of Extracts Of Allium cepa (Onions) And Zingiber officinale (Ginger) On Escherichia coli, Salmonella Typhi and Bacillus subtilis. J Trop Med. 2007 ; 3(2) : 1-7.

4. Bakht J, Khan S, Shafi M. Antimicrobial potentials of fresh Allium cepa against Gram positive and Gram negative bacteria and fungi. Pak J Bot. 2013; 45: 1-6.

5. Bakri I, Douglas C. Inhibitory effect of garlic extract on oral bacteria. Arch oral Biol. 2005 ; 50: 645-651.

6. Barbieri R, Coppo E, Marchese A, Daglia M, Sobarzo-Sánchez EN, Seyed FN, Seyed M. Phytochemicals for human disease: An update on plant-derived compounds antibacterial activity. Microbiol Res. 2017; 196:44-68.

7. Borlinghaus J, Albrecht F, Gruhlke M, Nwachukwu I. Slusarenko A. Allicin: chemistry and biological properties. Molecules. 2014; 19(8): 12591-12618.

8. Cheesebrough M. District Laboratory Practice In Tropical Countries. Part 2. , United Kingdom, Cambridge University Press. 2000

9. Corzo-Martinez $\mathrm{M}$, Corzo $\mathrm{N}$, Villamiel $\mathrm{M}$. Biological properties of onions and garlic. Trends Food Sci Technol. 2007; 18: 609-625.

10. Custovic A, Smajlovic J, Hadzic S, Ahmetagic $\mathrm{S}$, Tihic $\mathrm{N}$, Hadzagic $\mathrm{H}$. Epidemiological surveillance of bacterial nosocomial infections in the surgical intensive care unit. Mater sociomed. 2014; 26 (1): 7-11.

11. Ekor M. The growing use of herbal medicines: issues relating to adverse reactions and challenges in monitoring safety. Front Pharmacol. 2014; 4(177):177.

12. Ekwenye U, Elegalam N. Antibacterial activity of ginger (Zingiber officinale Roscoe) and garlic (Allium sativum L.) extracts on Escherichia coli and Salmonella Typhi. Intl J Molecular Adv Sci. 2005; 1: 411-416.

13. Eltaweel TM. Assessment of Antimicrobial Activity of Onion Extract (Allium cepa) on Staphylococcus aureus; in vitro study. International Conference on Chemical, Agricultural and Medical Sciences (CAMS2013) Dec, 2013. 29-30.

14. Epand RM., Epand RF. Lipid domains in bacterial membranes and the action of antimicrobial agents. Biochim Biophys Acta Biomembr. 2009; 1788: 289-294.

15. Esimone C, Okoye F, Odimegwu D, Nworu C, Oleghe $P$, Ejogha $P$. In vitro antimicrobial evaluation of lozenges containing extract of garlic and ginger. Intl J. Health Res. 2010 ; 3:105-110.

16. Hamza H. Antimicrobial activity of some plant extracts on microbial pathogens isolated from Hilla city hospitals. Iraq Med. J Babylon. 2015; 3: $96-102$.
17. Herzog K, Dusel JE, Hugentobler M, Beutin L, Sagesser G, Stephan R, Hachler H. NueschInderbinen M. Diarrheagenic enteroaggregative Escherichia coli causing urinary tract infection and bacteremia leading to sepsis. Infect. 2014 ; 42: 441-444.

18. Hindi NK. In vitro antibacterial activity of aquatic garlic extract, apple vinegar and apple vinegargarlic extract combination. Am. J Phytomed and Clin Ther. 2013; 1: 42-51.

19. Iwalokun B, Ogunledun A, Ogbolu D, Bamiro S, Jimi-Omojola J. In vitro antimicrobial properties of aqueous garlic extract against multidrugresistant bacteria and Candida species from Nigeria. J Med Food. 2004; 7, 327-333.

20. Joshi BS, Govind P, Basnet BB, Bhatt MR, Sharma D, Subedi K. et al. Phytochemical extraction and antimicrobial properties of different medicinal plants: Ocimum sanctum (Tulsi), Eugenia caryophyllata (Clove), Achyranthes bidentata (Datiwan) and Azadirachta indica (Neem) J. Microbiol Antimicrob. 2011; 3(1): 1-7.

21. Kabrah MAM, Faidah HS, Ashshi AM, Turkistani MSA. Antibacterial Effect of Onion. Sch J App Med Sci. 2016 ; 4: 4128-4133.

22. Kamenetsky RF, Adi M, Einat SM, Tomer BG, Chen K, Sagie E. et al. Integrated transcriptome catalogue and organ-specific profiling of gene expression in fertile garlic (Allium sativum L.) BMC Genomics 2015; 16 (1): 1-12.

23. Kim S, Kim D, Jin W, Park J, Yoon W. Lee Y. et al. Comparative studies of bioactive organosulphur compounds and antioxidant activities in garlic (Allium sativum L.), elephant garlic (Allium ampeloprasum L.) and onion (Allium cepa L.). Molecules 2018; 32(10):11931197.

24. Kyung $\mathrm{KH}$. Antimicrobial properties of Allium species. Curr Opin Biotechnol. 2012 ; 23: 142147.

25. Lekshmi NCJ, Gurueswari C. Viveka S. Evaluation of Garlic Extracts Effect on Three MRSA. Int J Biotechnol Bioeng Res. 2011 ; 2(1) : 45-54.

26. Liguori L, Califano R, Albanese D, Raimo $F$, Crescitell A, Di Matteo M. Chemical composition and antioxidant properties of five white onion (Allium cepa L.) landraces J. Food Qual. 2017; (2017) : 1-9.

27. Nejad ASM, Shabani S, Bayat M, Hosseini SE. Antibacterial effect of garlic aqueous extract on Staphylococcus aureus in Hamburger. Jundishapur J. Microbiol. 2014; 1-7.

28. Nicastro, HL. Ross SA. Milner, JA. Garlic and onions: their cancer prevention properties. Cancer Prevent Res. 2015; 8(3): 181-189.

29. Prestinaci F, Pezzotti, P, Pantosti A. Antimicrobial resistance: a global multifaceted phenomenon. Pathog Glob Health. 2015; 109: 309-318.

30. Santas J, Almajano MP, Carbo R. Antimicrobial and antioxidant activity of crude onion (Allium 
cepa, L.) extracts. Int J Food Sci Tech. 2010; 45: 403-409.

31. Santhosha SG, Jamuna P, Prabhavathi, SN. Bioactive components of garlic and their physiological role in health maintenance: $\mathrm{A}$ review Food Biosci. 2013; (3):59-74.

32. Savoia D. Plant-derived antimicrobial compounds: alternatives to antibiotics. Future Microbiol. 2012; 7(8): 979-990.

33. Schafer G, Kaschula C. The immunomodulation and anti-inflammatory effects of garlic organosulfur compounds in cancer chemoprevention. Anti-Cancer Agents Med. Chem. 2014; 14(2): 233-240.

34. Shakurfow F, Buazzi, MM, Gamal MA. Assessment of antimicrobial activity of onion (Allium cepa) and garlic (Allium sativum) extracts on Listeria monocytogenes in vitro study. Lebda Med J. 2016; $1: 1-5$.

35. Spellberg B, Guidos R, Gilbert D, Bradley J, Boucher HW, Scheld WM, Bartlett JG, Edwards JR, America ID. The epidemic of antibioticresistant infections: a call to action for the medical community from the Infectious Diseases Society of America. Clin Infect Dis. 2008; 46: 155-164.

36. Srinivasan D, Nathan $S$, Suresh $T$. Perumalsamy PL. Antimicrobial activity of certain Indian medicinal plants used in folkloric medicine. J Ethnopharmacol. 2001; 74: 217220.

37. Tagoe $D$ and Gbadago FA Comparison of the antimicrobial effectiveness of aqueous extracts of Garlic, Ginger and Lime and two conventional antibiotics on Escherichia coli, Salmonella spp., Shigella spp. and Bacillus cereus. Int J Microbiol. 2010; 8(2): 1-7

38. Uhlemann AC, Dordel J, Knox JR, Raven KE, Parkhill J, Holden M T, Peacock SJ, Lowy FD. Molecular tracing of the emergence, diversification, and transmission of $S$. aureus sequence type 8 in a New York community. Proc Natl Acad Sci. 2014; 111: 6738-6743.

39. Wagner S, Sommer R, Hinsberger S, Lu C, Hartmann RW, Empting M, Titz A. Novel strategies for the treatment of Pseudomonas aeruginosa infections. J. Med Chem. 2016: 59 : 5929-5969.

40. Wallock-Richard, D, Doherty CJ, Doherty L, Clarke DJ, Place M, Govan, JR. and Campopiano DJ. 2014. Garlic revisited: antimicrobial activity of allicin-containing garlic extracts against Burkholderia cepacia complex. PLoS One. 2014 ; 9: e112726.

41. Weigand I, Hilpert K, Hancock RE. Agar and broth dilution methods to determine the minimal inhibitory concentration (MIC) of antimicrobial substances. Nat Protoc. 2008; 3(2):163-75. 